\title{
Evaluation of ocular symptoms in COVID-19 subjects in inpatient and outpatient settings
}

\author{
Betül İlkay Sezgin Akçay • Esra Kardeş • Gülünay Kıray • Betül Ayaz • \\ Gülay Karakuş Hacıoğlu $\cdot$ Emin Pala
}

Received: 5 June 2020/ Accepted: 13 January 2021 / Published online: 24 January 2021

(C) The Author(s), under exclusive licence to Springer Nature B.V. part of Springer Nature 2021

\begin{abstract}
Purpose Evaluation of subtle ocular involvement and clinically significant conjunctivitis symptoms in a group of patients with COVID-19 in outpatient and inpatient settings.

Method Overall, 1083 patients infected with SARS$\mathrm{CoV}-2$ were recruited as subjects. Patients were divided into inpatients (group $1, n=371$ ) and outpatients (group 2, $n=712$ ). Demographical and general medical data included age, sex, and comorbidities. Patients whose diagnosis was confirmed by reversetranscriptase polymerase chain reaction (RT-PCR) were called by phone, and their chronic ocular disease, previous ocular surgery, ocular medication, contact lens wear and ocular irritation symptoms were queried during the active disease period.
\end{abstract}

The article was edited by American Journal Experts (AJE) . The certificate was issued on November 5, 2020 and may be verified on the AJE website using the verification code 634A85FB-E4D4-B09F-CD1B.

B. İ. Sezgin Akçay (凹) · E. Kardeş •

G. Karakuş Hacıoğlu

Ophthalmology Department, University of the Health

Sciences, Umraniye Training and Research Hospital,

İstanbul, Turkey

e-mail: betul_sezgin@yahoo.com

G. Kıray

Ophthalmology Department, University of Auckland,

Auckland, New Zealand
Results The mean age of the patients was $44.2 \pm 16.5$ (19-97) years; $635(58.6 \%)$ were male, and $448(41.4 \%)$ were female. Comorbidity, chronic ocular disease, ophthalmic medication and previous ocular surgery rates were significantly higher in group $1(p<0.05)$, while contact lens wear was not significantly different between groups. The main complaints received from patients were sore eye or burning sensation, foreign body sensation, itching and red eye and were significantly higher in group 1. Clinically significant conjunctivitis symptoms, such as red eye, ocular discharge and eyelid edema, were observed in 28 patients $(2.6 \%)$, with $14(3.8 \%)$ patients in group 1 and $14(2 \%)$ patients in group 2.

Conclusion Clinically significant conjunctivitis symptoms were detected in 28 subjects in the inpatient and outpatient groups. As systemic findings of COVID-19 intensify,

\footnotetext{
B. Ayaz

Internal Medicine Department, University of the Health Sciences, Umraniye Training and Research Hospital, Istanbul, Turkey

E. Pala

Family Medicine Department, University of the Health Sciences, Umraniye Training and Research Hospital, Istanbul, Turkey
} 
Keywords Coronavirus disease $2019 \cdot$ Severe acute respiratory syndrome coronavirus · Ocular irritation symptoms · Conjunctivitisocular irritation and conjunctivitis symptoms as red eye $\cdot$ Ocular discharge and eyelid

\section{Introduction}

A novel coronavirus (CoV), the Severe Acute Respiratory Syndrome Coronavirus-2 (SARS-CoV-2), was first reported in Wuhan, China on 31 December 2019 [1]. Coronavirus disease 2019 (COVID-19) was first noticed by an ophthalmologist, Dr. Li Wenliang, who unfortunately died of the same disease. The World Health Organization (WHO) declared COVID-19 a Public Health Emergency of International Concern on 30 January 2020 and a pandemic on 11 March 2020. The clinical presentation of COVID-19 is characterized by fever, cough, myalgia, malaise, dyspnea, hypoxia, tachypnea and some nonrespiratory symptoms, including gastrointestinal symptoms and conjunctivitis [2, 3].

SARS-CoV-2 enters target cells by binding of the viral Spike (S) protein to a specific cell-surface receptor called angiotensin converting enzyme 2 (ACE2) [4]. ACE2 helps to regulate blood pressure and is expressed in multiple tissues, including the lung alveolar mucosa, oral mucosa, gastrointestinal tract, kidneys and eye [5, 6]. The human eye has its own intraocular renin-angiotensin system, which is present on the ocular surface, trabecular meshwork, aqueous humor, iris, ciliary body, nonpigmented ciliary epithelium, and retina [7]. Tissues expressing ACE2 are defined as potential infection routes of SARS-CoV-2 $[8,9]$. The routes of transmission of SARS-CoV-2 are airborne dissemination through respiratory droplets, the fecal-oral route and direct/indirect contact to the face and eye. Although the main route of virus transmission is through respiratory droplets, several studies have raised concern about infection occurring through ocular secretions [10].

In this study, we investigated ocular symptoms reported by patients who have a confirmed diagnosis of COVID-19 in order to determine the prevalence of conjunctivitis associated with this disease, highlighting the presence of subtle ocular involvement in inpatient and outpatient settings.

\section{Methods}

The study was approved by the Ethics Committee of the University of Health Sciences, Umraniye Education and Research Hospital and was performed in accordance with the tenets of the Declaration of Helsinki. Overall, 1083 patients in Umraniye Education and Research Hospital who received a COVID-19 diagnosis were recruited from inpatient and outpatient settings between 20 March and 13 May 2020.

Demographical and general medical data were retrospectively obtained from the hospital database, including age, sex and comorbidities. All subjects participating in the study provided written consent for the medical records to be reviewed for the approved research purposes.

A confirmed case of COVID-19 was defined as a positive result by real-time reverse-transcriptase polymerase chain reaction (RT-PCR) assay of nasal and pharyngeal swab specimens. Base decisions on admission of individuals to inpatient settings were made according to SARS-CoV-2 guidelines of the Ministry of Health [11]. Disease severity was identified as mild, moderate or severe. Mild infection was defined as symptoms including fever, cough, myalgia and $\mathrm{SPO}_{2}$ greater than $93 \%$ in room air and without dyspnea, hypoxia, tachypnea, or underlying additional comorbidities (e.g., hypertension, diabetes mellitus, cancer, chronic obstructive pulmonary disease, immunosuppression) in individuals $<50$ years of age. Home care facilities were feasible for patients with uncomplicated infection and were isolated in outpatient settings. Moderate infection was identified as pneumonia with signs and symptoms of fever, cough, dyspnea, hypoxia, tachypnea (respiratory rate less than 30/minute), $\mathrm{SPO}_{2}$ greater than $90 \%$, ground-glass opacity and/or segmental consolidation in chest CT and/or patients with additional comorbidities. These patients were hospitalized in isolated rooms. Patients with severe infection who presented with pneumonia and signs of dyspnea, hypoxia, tachypnea (respiratory rate greater than 30/minute), $\mathrm{SPO}_{2}$ less than $90 \%$ in room air and with bilateral diffuse consolidation in chest CT were admitted to the intensive care unit (ICU). Only PCR-confirmed mild and moderate cases were included in the study; patients with severe infection were not included.

In total, 1083 patients (371 inpatients and 712 outpatients) underwent phone consultation by an 
examiner (BS). The purpose of the study and research procedures were explained, and agreement to participation was obtained. Detailed ocular history was recorded, including previous ocular surgery, past or present history of any ocular disease, contact lens wear and present history of any ophthalmic medications used. Patients were questioned for ocular irritation symptoms, including sore eye, itching, foreign body sensation, redness, any increase in ocular secretions and edema of eyelids developed during COVID-19.

\section{Statistical analysis}

All statistical analyses were performed using SPSS (Statistical Package of the Social Sciences, SPSS Inc., Chicago, IL) version 25.0 software. Categorical variables were described as the frequency rates and percentages. Normally distributed data were described as the means and standard deviations (SD) with the Kolmogorov-Smirnov test. Chi square analysis was used for parametric data, and $p<0.05$ was considered statistically significant.

\section{Results}

Overall, 1083 patients (448 females and 635 males) were included in the study. Patients were classified as inpatient (group 1) or outpatient (group 2). Group 1 consisted of 371 (174 females and 197 males) inpatient subjects with a mean age of $55 \pm 17.1$ (21-97), and group 2 consisted of 712 (274 females and 438 males) outpatient subjects with a mean age of $38 \pm 12.9$ (19-67). The comorbidities detected in group 1 were hypertension $(n=24,6.4 \%)$, diabetes mellitus $(n=10,2.7 \%)$, allergic asthma $(n=2$, $0.53 \%)$, congestive heart failure $(n=10,2.7 \%)$, Hashimoto disease $(n=3,0.80 \%)$, chronic renal failure $(n=2,0.53 \%)$, rheumatoid arthritis $(n=1$, $0.26 \%$ ), and lymphoma ( $n=1,0.26 \%)$; in group 2 , the comorbidities were hypertension $(n=8,1.1 \%)$, diabetes mellitus ( $n=4,0.56 \%)$ and Hashimoto disease $(n=1,0.14 \%)$. The comorbidities detected in group 1 were significantly higher than in group $2(p<0.001)$. The demographic and general medical data of all cohorts and each group are shown in Table 1.

The ocular characteristics of each group were identified, including chronic ocular disease, previous ocular surgery, ophthalmic medications and contact lens wear. In group 1, the chronic ocular diseases found among subjects were senile macular degeneration $(n=6,1.6 \%)$, dry eye $(n=11,2.9 \%)$, glaucoma $(n=1,0.26 \%)$ and diabetic retinopathy $(n=4$, $1.07 \%)$, while those of group 2 were dry eye $(n=3$, $0.42 \%)$, keratoconus $(n=1,0.14 \%)$ and vernal conjunctivitis $(0.14 \%)$. In terms of previous ocular surgery, 24 patients $(6.4 \%)$ underwent phacoemulsification and one patient dacryocystorhinostomy $(0.3 \%)$ in group 1 ; however, five $(0.7 \%)$ patients underwent phacoemulsification and one patient corneal collagen-crosslinking $(0.14 \%)$ in group 2 . The ophthalmic medications used in group 1 were artificial tears $(n=11,2.9 \%)$ and topical antiglaucomatous agent $(n=1,0.26 \%)$, while those in group 2 were artificial tear $(n=3,0.42 \%)$ and topical cyclosporin $(n=1,0.14 \%)$. Ophthalmic medication usage and previous ocular surgery figures were significantly higher in group $1(p<0.001)$, while contact lens wear was similar between the two groups $(p=0.83)$. The ocular characteristics of all cohorts and each group are shown in Table 2.

Patients were surveyed in terms of ocular irritation symptoms after the onset of disease. The complaints of the patients were classified according to the most frequent answers with increasing severity for statistical analysis. Sore eye or burning sensation was the most common symptom in each group (8.9\% in group 1 and $6 \%$ in group 2). Other complaints were foreign body sensation, itching, red eye, and significant ocular discharge with eyelid edema in descending order. Ocular symptoms were significantly higher in group 1 . Ocular symptoms of all cohorts and each group are shown in Table 3.

Clinically significant conjunctivitis symptoms were observed in $28(2.6 \%)$ patients (19 females and 9 males) in the overall cohort, with $14(3.8 \%)$ patients in group 1 and $14(2 \%)$ in group 2 . The mean age was $47.1 \pm 3.5$ (range 21 to 81 years). Conjunctivitis symptoms appeared at the first week of disease onset in four patients $(28.5 \%)$ and the second week in ten patients $(71.4 \%)$. The ocular and demographic data, onset of symptoms and detailed symptoms of patients who had definitive conjunctivitis are shown in Table 4. 
Table 1 Baseline characteristics of all subjects and each group

\begin{tabular}{lccc}
\hline & All subjects $n=1083$ & Group $1 n=371$ & Group $2 n=712$ \\
\hline Age $($ range,SD)y & $44.216,5(19-97)$ & $5517.1(21-97)$ & $3812.9(19-67)$ \\
Sex & & & \\
Female, $(n \%)$ & $448(41.4 \%)$ & $174(46.9 \%)$ & $274(38.5 \%)$ \\
Male, $(n \%)$ & $635(58.6 \%)$ & $197(53.1 \%)$ & $438(61.5 \%)$ \\
Comorbidities & $66(6.09 \%)$ & $53(27.8 \%)$ & $13(1.8 \%)$ \\
Yes, $n(\%)$ & $1017(93.91 \%)$ & $318(72.2 \%)$ & $358(8.2 \%)$ \\
No, $n(\%)$ & & & $p<0.001$ \\
\hline
\end{tabular}

* Comparison of comorbidities in inpatient and outpatient groups by Chi-square test shows statistical significance (p $<0.05, \mathrm{SD}$, Standard Deviation)

Table 2 Ocular characteristics of all subjects and each group
* Comparison of ocular characteristics of inpatient and outpatient groups by Chi-square test shows statistical significance $(p<0.05)$

\begin{tabular}{|c|c|c|c|c|}
\hline & All subjects $n=1083$ & Group $1 n=371$ & Group $2 n=712$ & $P$ value ${ }^{*}$ \\
\hline \multicolumn{5}{|c|}{ Chronic ocular disease } \\
\hline Yes, $n(\%)$ & $27(2.49 \%)$ & $22(5.92 \%)$ & $5(0.7 \%)$ & \multirow[t]{2}{*}{$p<0.001$} \\
\hline No, $n(\%)$ & $1056(97.5 \%)$ & $349(94.07 \%)$ & $707(99.3 \%)$ & \\
\hline \multicolumn{5}{|c|}{ Previous ocular surgery } \\
\hline Yes, $n(\%)$ & $31(2.8 \%)$ & $25(6.73 \%)$ & $6(0.84 \%)$ & \multirow[t]{2}{*}{$p<0.001$} \\
\hline No, $n(\%)$ & $1052(97.13 \%)$ & $346(93.2 \%)$ & $706(99.15 \%)$ & \\
\hline \multicolumn{5}{|c|}{ Ophthalmic medication used } \\
\hline Yes, $n(\%)$ & $16(1.4 \%)$ & $12(3.2 \%)$ & $4(0.56 \%)$ & \multirow[t]{2}{*}{$p<0.001$} \\
\hline No, $n(\%)$ & $1067(98.6 \%)$ & $359(96.8 \%)$ & $708(99.43 \%)$ & \\
\hline \multicolumn{5}{|c|}{ Contact lens wear } \\
\hline Yes, $n(\%)$ & $3(0.27 \%)$ & $1(0.26 \%)$ & $2(0.28 \%)$ & \multirow[t]{2}{*}{$p=0.838$} \\
\hline No, $n(\%)$ & $1080(99.7 \%)$ & $370(99.7 \%)$ & $710(99.7 \%)$ & \\
\hline
\end{tabular}

Table 3 Ocular symptoms of all subjects and each group

\begin{tabular}{|c|c|c|c|c|}
\hline & All subjects $n=1083$ & Group $1 n=371$ & Group $2 n=712$ & $P$ value ${ }^{*}$ \\
\hline \multicolumn{5}{|c|}{ Sore eye or burning sensation } \\
\hline Yes, $n(\%)$ & $65(6 \%)$ & $33(8.9 \%)$ & $32(\% 4.5)$ & \multirow[t]{2}{*}{$p=0.007$} \\
\hline No, $n(\%)$ & $1018(94 \%)$ & $338(91.1 \%)$ & $680(95.5 \%)$ & \\
\hline \multicolumn{5}{|c|}{ Foreign body sensation \pm burning sensation, } \\
\hline Yes, $n(\%)$ & $39(3.6 \%)$ & $23(6.2 \%)$ & $16(2.2 \%)$ & \multirow[t]{2}{*}{$p=0.002$} \\
\hline No, $n(\%)$ & $1044(96.4 \%)$ & $348(93.8 \%)$ & $696(97.8 \%)$ & \\
\hline \multicolumn{5}{|c|}{ Red eye \pm foreign body sensation, burning sensation, pain, itching } \\
\hline Yes, $n(\%)$ & $37(3.4 \%)$ & $23(6.2 \%)$ & $14(2 \%)$ & \multirow[t]{2}{*}{$p=0.001$} \\
\hline No, $n(\%)$ & $1046(96.6 \%)$ & $348(93.8 \%)$ & $698(98 \%)$ & \\
\hline \multicolumn{5}{|c|}{ Significant ocular discharge, red eye, \pm eyelid edema foreign body sensation, burning sensation,pain, itching } \\
\hline Yes, $n(\%)$ & $28(2.6 \%)$ & $14(3.8 \%)$ & $14(2.0 \%)$ & \multirow[t]{2}{*}{$p=0.015$} \\
\hline No, $n(\%)$ & $1055(97.4)$ & $357(96.2 \%)$ & $698(98 \%)$ & \\
\hline
\end{tabular}

* Comparison of ocular irritation rates in inpatient and outpatient groups by Chi-square test shows statistical significance $(p<0.05)$ 
Table 4 Demographic data, systemic and ocular comorbidities and onset of ocular symptoms of patients describing clinically significant conjunctivitis symptoms

\begin{tabular}{|c|c|c|c|c|c|}
\hline Patient & Age(y) Sex & $\begin{array}{l}\text { Disease severity } \\
\text { /group }\end{array}$ & Comorbidities & $\begin{array}{l}\text { Ocular } \\
\text { characteristics }\end{array}$ & Ocular symptoms /onset of symptoms \\
\hline 1 & $\begin{array}{l}46 \mathrm{y}, \\
\text { female }\end{array}$ & Moderate/group1 & None & None & $\begin{array}{l}\text { Discharge, red eye, eyelid edema, foreign body } \\
\text { sensation/second week of onset of respiratory } \\
\text { symptoms }\end{array}$ \\
\hline 2 & $\begin{array}{l}23 \text { y, } \\
\text { female }\end{array}$ & Moderate/group1 & None & None & $\begin{array}{l}\text { Discharge, red eye, eyelid edema, itching, } \\
\text { photophobia/first week of onset of respiratory } \\
\text { symptoms }\end{array}$ \\
\hline 3 & $\begin{array}{l}31 \mathrm{y}, \\
\text { female }\end{array}$ & Moderate/group1 & None & None & $\begin{array}{l}\text { Discharge, red eye, sore eye/second week of onset of } \\
\text { respiratory symptoms }\end{array}$ \\
\hline 4 & $58 \mathrm{y}$, male & Moderate/group1 & HT & None & $\begin{array}{l}\text { Discharge, red eye, eyelid edema, foreign body } \\
\text { sensation/first week of onset of respiratory symptoms }\end{array}$ \\
\hline 5 & $\begin{array}{l}44 \mathrm{y}, \\
\text { female }\end{array}$ & Moderate/group1 & None & None & $\begin{array}{l}\text { Discharge, red eye, eyelid edema, sore eye/second week } \\
\text { of onset of respiratory symptoms }\end{array}$ \\
\hline 6 & $\begin{array}{l}29 \mathrm{y}, \\
\text { female }\end{array}$ & Moderate/group1 & None & None & $\begin{array}{l}\text { Discharge, red eye, eyelid edema, sore eye/second week } \\
\text { of onset of respiratory symptoms }\end{array}$ \\
\hline 7 & $58 \mathrm{y}$, male & Moderate/group1 & None & None & $\begin{array}{l}\text { Discharge, red eye, eyelid edema, foreign body } \\
\text { sensation, sore eye } \\
\text { second week of onset of respiratory symptoms }\end{array}$ \\
\hline 8 & $66 \mathrm{y}$, male & Moderate/group1 & None & None & $\begin{array}{l}\text { Discharge, red eye, eyelid edema, foreign body } \\
\text { sensation, sore eye } \\
\text { second week of onset of respiratory symptoms }\end{array}$ \\
\hline 9 & $\begin{array}{l}78 \text { y, } \\
\text { female }\end{array}$ & Moderate/group1 & None & $\begin{array}{l}\text { Cataract } \\
\text { surgery }\end{array}$ & $\begin{array}{l}\text { Discharge, red eye, eyelid edema, pain } \\
\text { second week of onset of respiratory symptoms }\end{array}$ \\
\hline 10 & $\begin{array}{l}54 \text { y, } \\
\text { female }\end{array}$ & Moderate/group1 & None & None & $\begin{array}{l}\text { Discharge, red eye,sore eye,foreing body sensation, } \\
\text { first week of onset of respiratory symptoms }\end{array}$ \\
\hline 11 & $55 \mathrm{y}$, male & Moderate/group1 & None & None & $\begin{array}{l}\text { Discharge, red eye, eyelid edema, foreign body } \\
\text { sensation } \\
\text { /first week of onset of respiratory symptoms }\end{array}$ \\
\hline 12 & $81 \mathrm{y}$, male & Moderate/group1 & $\mathrm{CHF}$ & $\begin{array}{l}\text { Cataract } \\
\text { surgery }\end{array}$ & $\begin{array}{l}\text { Discharge, red eye, eyelid edema, sore eye,pain first } \\
\text { week of onset of respiratory symptoms }\end{array}$ \\
\hline 13 & $\begin{array}{l}32 \mathrm{y}, \\
\text { female }\end{array}$ & Moderate/group1 & None & None & $\begin{array}{l}\text { Discharge, red eye, eyelid edema, sore eye, pain first } \\
\text { week of onset of respiratory symptoms }\end{array}$ \\
\hline 14 & $\begin{array}{l}\text { 41y, } \\
\text { female }\end{array}$ & Moderate/group1 & None & None & $\begin{array}{l}\text { Discharge, red eye, eyelid edema, foreign body } \\
\text { sensation,sore eye second week of onset of respiratory } \\
\text { symptoms }\end{array}$ \\
\hline 15 & $\begin{array}{l}33 \mathrm{y}, \\
\text { female }\end{array}$ & Mild/group2 & None & None & $\begin{array}{l}\text { Discharge, red eye, eyelid edema, pain,itcing /second } \\
\text { week of onset of fever }\end{array}$ \\
\hline 16 & $21 \mathrm{y}$, male & Mild/group2 & None & $\begin{array}{l}\text { Contact lens } \\
\text { wear }\end{array}$ & $\begin{array}{l}\text { Discharge, red eye, eyelid edema, pain/second week of } \\
\text { onset of fever }\end{array}$ \\
\hline 17 & $\begin{array}{l}27 \mathrm{y}, \\
\text { female }\end{array}$ & Mild/group2 & None & None & $\begin{array}{l}\text { Discharge, red eye, eyelid edema, sore eye/first week of } \\
\text { onset of fever }\end{array}$ \\
\hline 18 & $\begin{array}{l}45 \mathrm{y}, \\
\text { female }\end{array}$ & Mild/group2 & None & None & $\begin{array}{l}\text { Discharge, red eye, eyelid edema, foreign body } \\
\text { sensation,sore eye,photophobia/first week of onset of } \\
\text { fever/5-7 days }\end{array}$ \\
\hline 19 & $\begin{array}{l}60 \mathrm{y}, \\
\text { female }\end{array}$ & Mild/group2 & None & None & $\begin{array}{l}\text { Discharge, red eye, eyelid edema, foreign body } \\
\text { sensation,sore eye/first week of onset of fever }\end{array}$ \\
\hline 20 & $\begin{array}{l}51 \mathrm{y}, \\
\text { female }\end{array}$ & Mild/group2 & None & None & $\begin{array}{l}\text { Discharge, red eye, eyelid edema, sore eye/first week of } \\
\text { onset of fever }\end{array}$ \\
\hline
\end{tabular}


Table 4 continued

\begin{tabular}{|c|c|c|c|c|c|}
\hline Patient & Age(y) Sex & $\begin{array}{l}\text { Disease severity } \\
\text { /group }\end{array}$ & Comorbidities & $\begin{array}{l}\text { Ocular } \\
\text { characteristics }\end{array}$ & Ocular symptoms /onset of symptoms \\
\hline 21 & $\begin{array}{l}30 \mathrm{y}, \\
\text { female }\end{array}$ & Mild/group2 & None & None & $\begin{array}{l}\text { Discharge, red eye, sore eye, foreign body } \\
\text { sensation/first week of onset of fever }\end{array}$ \\
\hline 22 & $\begin{array}{l}43 \mathrm{y}, \\
\text { female }\end{array}$ & Mild/group2 & None & None & $\begin{array}{l}\text { Discharge, red eye, sore eye/second week of onset of } \\
\text { fever }\end{array}$ \\
\hline 23 & $40 \mathrm{y}$, male & Mild/group2 & None & None & $\begin{array}{l}\text { Discharge, red eye, eyelid edema, foreign body } \\
\text { sensation, first week of onset of fever }\end{array}$ \\
\hline 24 & $\begin{array}{l}62 \mathrm{y}, \\
\text { female }\end{array}$ & Mild/group2 & HT & $\begin{array}{l}\text { Dry eye } \\
\text { Artificial } \\
\text { tears }\end{array}$ & $\begin{array}{l}\text { Discharge, red eye, eyelid edema, foreign body } \\
\text { sensation,itching/first week of onset of fever }\end{array}$ \\
\hline 25 & $55 \mathrm{y}$, male & Mild/group2 & None & None & $\begin{array}{l}\text { Discharge, red eye, eyelid edema,sore eye/ } \\
\text { second week of onset of respiratory symptoms, }\end{array}$ \\
\hline 26 & $61 \mathrm{y}$, male & Mild/group2 & None & None & $\begin{array}{l}\text { Discharge, red eye, foreign body sensation, sore eye / } \\
\text { first week of onset of fever }\end{array}$ \\
\hline 27 & $\begin{array}{l}39 \mathrm{y}, \\
\text { female }\end{array}$ & Mild/group2 & None & None & $\begin{array}{l}\text { Discharge, red eye, eyelid edema, itching, sore eye/first } \\
\text { week of onset of fever }\end{array}$ \\
\hline 28 & $\begin{array}{l}49 \mathrm{y} \\
\text { female }\end{array}$ & Mild/group2 & None & None & $\begin{array}{l}\text { Discharge, red eye, eyelid edema, foreign body } \\
\text { sensation, pain/first week of onset of fever }\end{array}$ \\
\hline
\end{tabular}

HT, Hypertension; CHF, Congestive Heart Failure, y, Years

\section{Discussion}

Respiratory viruses, e.g., adenovirus and influenza virus, have been documented to possess ocular tropism, leading to keratoconjunctivitis or conjunctivitis in infected individuals [12]. Despite using the ocular surface as a portal of entry to the respiratory system, coronaviruses are occasionally associated with clinically significant conjunctivitis, except for HCoV-NL63. 2.2 [13].The potential route of viral particles through ocular secretions remain unclear for SARS-CoV-2. Possible theories include direct inoculation of the ocular surface by respiratory aerosols, migration of viral load from the nasopharynx via nasolacrimal duct or hematogenous spread through the lacrimal gland [10].

We surveyed a total of 1083 patients with COVID19 in terms of ocular irritation symptoms. According to our results, the most common symptom in all patients was burning sensation or sore eye $(6 \%)$. Other common symptoms reported by patients were foreign body sensation, itching, red eye, significant watery discharge and eyelid edema. Clinically significant conjunctivitis symptoms were present in 28 patients (2.6\%). Conjunctivitis symptoms began at the second week of disease onset in $71.4 \%$ and at the first week in $28.5 \%$ of patients. According to patient responses, ocular symptoms were observed at a higher rate in the inpatient group. The prevalence of conjunctivitis in patients with COVID-19 is controversial in the literature. Guan et al. documented 'conjunctival congestion' in $9(0.8 \%)$ of 1099 laboratory confirmed COVID-19 cases, which frequently occurred in patients with more severe COVID-19 [3]. Although there is a low prevalence of SARS-CoV-2 in tears, it is possible to transmit via the eyes. Wu et al. evaluated 38 confirmed cases of COVID-19 by rRT-PCR, and they detected the incidence of conjunctivitis in $31.6 \%$ of hospitalized patients [14]. Similar to our report, they concluded that ocular findings tend to be more frequent in patients with more severe COVID-19. Xia et al. evaluated the conjunctival secretions of 30 confirmed cases of COVID-19 by rRT-PCR, and SARS-CoV-2 RNA was identified in tears and conjunctival samples from one infected individual [15]. They also reported that patients with ocular symptoms were more likely to have higher white blood cell and neutrophil counts and higher levels of procalcitonin, C-reactive protein, and lactate dehydrogenase than patients without ocular symptoms. Hung et al. evaluated 56 hospitalized patients infected with SARS-CoV-2 to assess the anterior ocular surface using the Ocular Surface Disease Index (OSDI) and Salisbury Eye Evaluation Questionnaire (SEEQ) 
before and after the onset of disease. They found that ocular irritation symptoms were aggravated in $27 \%$ of patients after the onset of disease [16]. Shemer et al. evaluated ocular involvement in COVID -19 in terms of clinical and molecular basis. They found that active conjunctival injection was detected in one out of five cases and found to be associated with loss of smell and taste [17].

Current management of COVID-19 is mainly supportive. Beside antiviral medications, hydroxychloroquine and azithromycin combination is a possible therapeutic protocol [18]. Nicolo et al. conducted a comprehensive literature search about hydroxychloroquine and chloroquine on retinal safety in COVID-19 outbreak and concluded that drug-related retinal toxicity may represent a major safety concern and appropriate screening strategies, such as telemedicine, should be considered [19].

The most important limitation of this study is the reliance on subjective responses of individuals. Slit lamp examinations could not be performed for each patient with ocular symptoms because of the quarantine protocols during the active phase of the disease. One examiner (BS) conducted all the telephone interviews with subjects to prevent interexaminer bias.

In summary, we assessed ocular symptoms in inpatient and outpatient settings among a cohort of patients with COVID-19. Our data revealed a higher incidence of ocular irritation and conjunctivitis symptoms in the hospitalized group. We concluded that as the systemic findings of the disease intensify, ocular irritation symptoms increase. To the best of our knowledge, no reports in the literature have compared ocular symptoms according to the severity of COVID19. Although the possibility of viral transmission through tears is rather low, a conjunctivitis rate of $2.6 \%$ could increase transmission between patients and physicians, or vice versa, via exposure to a patient's breath during an ophthalmic examination. Personal protective equipment, including gown, gloves, certified N95 mask, and eye shield/goggles, should be worn when examining COVID patients for occupational safety. Eye care providers should be encouraged to use slit lamp breath shields, and patients should be advised not to speak during slit lamp examination.

Funding The authors received no financial support for the research, authorship, and/or publication of this article.

\section{Compliance with ethical standards}

Conflict of interest The author declared that they have no conflict of interest.

Ethical approval All procedures performed in studies involving human participants were in accordance with the ethical standards of the institutional and/or national research committee and with the 1964 Helsinki declaration and its later amendments or comparable ethical standards. Informed consent was obtained from each patient.

Human or animal rights This article does not contain any studies with animals performed by any of the authors.

\section{References}

1. Wang C, Horby PW, Hayden FG, Gao GF (2020) A novel coronavirus outbreak of global health concern. Lancet 395(10223):470-473. https://doi.org/10.1016/S01406736(20)30185-9

2. Gu J, Han B, Wang J (2020) COVID-19: gastrointestinal manifestations and potential fecal-oral transmission. Gastroenterology 19:0016-5085. https://doi.org/10.1053/j. gastro.2020.02.054

3. Guan WJ, Ni ZY, Hu Y et al (2020) Clinical characteristics of coronavirus disease 2019 in China. N Engl J Med. https:// doi.org/10.1056/NEJMoa2002032

4. Hoffmann M, Kleine-Weber H, Schroeder S, Krüger N, Herrler T, Erichsen S, Schiergens TS, Herrler G, Wu NH, Nitsche A et al (2020) SARS-CoV-2 cell entry depends on ACE2 and TMPRSS2 and is blocked by a clinically-proven protease inhibitor. Cell. https://doi.org/10.1016/j.cell.2020. 02.052

5. Baig AM, Khaleeq A, Ali U, Syeda H (2020) (2020): Evidence of the COVID-19 virus targeting the CNS: tissue distribution, host-virus interaction, and proposed neurotropic mechanisms. ACS Chem Neurosci 11:995-998. https://doi.org/10.1021/acschemneuro.0c00122

6. Yan R, Zhang Y, Li Y, Xia L, Guo Y, Zhou Q (2020) Structural basis for the recognition of SARS-CoV-2 by fulllength human ACE2. Science 367:1444-1448. https://doi. org/10.1126/science.abb2762

7. Holappa M, Vapaatalo H, Vaajanen A (2020) Many faces of renin-angiotensin system-focus on eye. Open Ophthalmol J 11:122. https://doi.org/10.2174/1874364101711010122

8. Hamming I, Timens W, Bulthuis ML, Lely AT, Navis G, van Goor H (2004) Tissue distribution of ACE2 protein, the functional receptor for SARS coronavirus. A first step in understanding SARS pathogenesis. J Pathol 203(2):631-637. https://doi.org/10.1002/path.1570

9. Xu H, Zhong L, Deng J, Peng J, Dan H, Zeng X, Li T, Chen Q (2020) High expression of ACE2 receptor of 2019-nCoV on the epithelial cells of oral mucosa. Int J Oral Sci 12(1):8. https://doi.org/10.1038/s41368-020-0074-x

10. Napoli PE, Nioi M, d'AlojaE FM (2020) The ocular surface and the coronavirus disease 2019: does a dual 'ocular route' exist? Clin Med 9:1269. https://doi.org/10.3390/ jcm9051269 
11. Ministry of Health (2020). COVID-19 Guidelines [online]. Website. https://covid19bilgi.saglik.gov.tr/tr/algoritmalar. Accessed 17Apr 2020

12. Belser JA, Rota PA, Tumpey TM (2013) Ocular tropism of respiratory viruses. Microbiol Mol Biol Rev 77(1):144-156. https://doi.org/10.1128/MMBR.00058-12

13. Vabret A, Mourez T, Dina J, van der Hoek L, Gouarin S, Petitjean J, Brouard J, Freymuth F (2005) Human coronavirus NL63, France. Emerg Infect Dis 11(8):1225-1229. https://doi.org/10.3201/eid1108.050110

14. Wu P, Duan F, Luo C, Liu Q, Qu X, Liang L, Wu K (2020) Characteristics of ocular findings of patients with coronavirus disease 2019 (COVID-19) in Hubei province. JAMA Ophthalmol, China. https://doi.org/10.1001/jamaophthalmol. 2020.1291

15. Xia J, Tong J, Liu M, ShenY GuoD (2020) Evaluation of coronavirus in tears and conjunctival secretions of patients with SARS-CoV-2 infection. J Med Virol. https://doi.org/ $10.1002 / j m v .25725$

16. Hong N, Yu W, Xia J, Shen Y, Yap M, Wei HW (2020) Evaluation of ocular symptoms and tropism of SARS-CoV-
2 in patients confirmed with COVID-19. Acta Ophthalmol. https://doi.org/10.1111/aos.14445

17. Shemer A, Einan-Lifshitz A, Itah A, Dubinsky-Pertzov B, Pras E, Hecht I (2020) Ocular involvement in coronavirus disease 2019 (COVID-19): a clinical and molecular analysis. Int Ophthalmol 14:1-8. https://doi.org/10.1007/s10792020-01592-1

18. Neri P, Pichi F (2020) COVID-19 and the eye immunity lesson learned from the past and possible new therapeutic insights. Int Ophthalmol. 40(5):1057-1060. https://doi.org/ 10.1007/s10792-020-01389-2

19. Nicolò M, Ferro Desideri L, Bassetti M, Traverso CE (2020) Hydroxychloroquine and chloroquine retinal safety concerns during COVID-19 outbreak. Int Ophthalmol 18:1-7. https://doi.org/10.1007/s10792-020-01593-0

Publisher's Note Springer Nature remains neutral with regard to jurisdictional claims in published maps and institutional affiliations. 